Int. J. Electrochem. Sci., 11 (2016) 10895 - 10905

International Journal of

ELECTROCHEMICAL

SCIENCE

www.electrochemsci.org

\title{
Effect of Sulphide Addition to Chloride Environment on Corrosion Behavior of SAF2507 Duplex Stainless Steel
}

\section{Zhiyuan Zhu}

Jiangsu University of Science and Technology, Materials Science and Engineering, Zhenjiang 212003 E-mail: salanganezhu@163.com

doi: $10.20964 / 2016.12 .95$

Received: 5 September 2016 / Accepted: 23 October 2016 / Published: 10 November 2016

The effect of sulphide addition to chloride environment on corrosion behavior of SAF2507 stainless steel at different temperatures was studied by slow strain rate test and electrochemical test, the tensile fracture morphology was observed by SEM. The results indicated that sulphide could enhance the stress corrosion susceptibility of SAF2507 duplex stainless steel. In addition sulphide made the general corrosion resistance of SAF2507 duplex stainless steel decrease. With the increase of temperature the effect of sulphide on rising corrosion susceptibility of steel was more obvious. In addition, sulphide made corrosion pits occured in ferrite-austenite phase boundaries become increasing.

Keywords: SAF2507 Duplex Stainless Steel; Sulphide; Stress corrosion cracking; Electrochemical corrosion;

\section{$\underline{\text { FULL TEXT }}$}

(C) 2016 The Authors. Published by ESG (www.electrochemsci.org). This article is an open access article distributed under the terms and conditions of the Creative Commons Attribution license (http://creativecommons.org/licenses/by/4.0/). 